J. Clin. Chem. Clin. Biochem.

Vol. 16, 1978, pp. 19-23

\title{
Additional Precipitation Reactions of Lectins with Human Serum Glycoproteins
}

\author{
G. Uhlenbruck ${ }^{1}$ ), B. A. Baldo, G. Steinhausen ${ }^{1}$ ), H. G. Schwick, B. P. Chatterjee ${ }^{1}$ ), V. Hơejßi, A. Krajhanzl and \\ J. Kocourek ${ }^{2}$ )
}

Medical University Clinic Cologne, Behringwerke AG, Marburg and Department of Biochemistry, Charles University, Prague

(Received May 6, 1977)

\section{Dedicated in memoriam Dr. K. Heide}

Summary: Highly purified human serum glycoproteins were treated with neuraminidase and examined for their cross reaction with several lectins with anti-galactosyl specificity: $\beta$ - $D$-galactosyl structures are thought to be the main terminal sugar residues that become attached de novo after removal of neuraminic acid. The following lectins were tested: Tridacnin from the bivalve clams Tridacna maxima and Tridacna gigas, the agglutinin from the sponge Axinella polypoides, the lectin from the roach Rutilus rutilus and the plant lectins from Ricinus communis, Ononis spinosa, Glycine soja and Abrus precatorius. In agar gel diffusion, these purified and precipitating lectins gave more or less strong or negative results against the different neuraminidase-treated serum glycoproteins, thus indicating subtle differences with respect to their anti-galactosyl combining specificity. On the other hand, serum glycoproteins which reacted with the same lectin, did not always show complete identity lines. Finally, as revealed by these lectins, the carbohydrate moiety of serum glycoproteins may reflect a complex and broad spectrum of heterogeneity. This could lead to a more detailed understanding of the topographical and steric arrangement of the chemical structure and of the biological role of carbohydrate groups in these glycosubstances.

\section{Zusätzliche Fällungsreaktionen von Lectinen mit Glykoproteinen aus Menschenseren}

Zusammenfassung: Menschliche Serum-Glykoproteine wurden mit Neuraminidase behandelt und im Hinblick auf ihre Kreuzreaktionen mit verschiedenen Lectinen mit Anti-Galactosyl-Spezifität untersucht. Es wird angenommen, daß $\beta-D$-Galactosyl-Strukturen in der Regel diejenigen Zuckerreste sind, welche nach Entfernung der Neuraminsäure endständig werden. Folgende Lectine wurden getestet: Tridacnin aus den Muscheln Tridacna maxima und Tridacna gigas, das Agglutinin vom Schwamm Axinella polypoides, das Lectin aus der Plötze Rutilus rutilus und die Pflanzenlectine aus Ricinus communis, Ononis spinosa, Glycine soja und Abrus precatorius. Die gereinigten, präzipitierenden Lectine gaben mehr oder weniger starke Präzipitate, wenn sie im Agargel gegen verschiedene, Neuraminidase-behandelte SerumĞlykoproteine diffundierten. Auf diese Weise konnten feine Unterschiede bezüglich der Anti-Galactosyl-Spezifität aufgezeigt werden, während andererseits Serum-Glykoproteine, die mit demselben Lectin reagierten, nicht immer vollständige Identitätslinien ergäben. Die Ergebnisse deuten an, wie komplex und heterogen der Kohlenhydratanteil dieser Serum-Glykoproteine ist, wenn man ihn mit mehreren Lectinen untersucht. Aber nur so gewinnt man ein detailliertes Bild von der topographischen und sterischen Anordnung dieser Kohlenhydratketten in diesen Glykosubstanzen und kann etwas über ihre Chemie und biologische Bedeutung in Erfahrung bringen.

\section{Introduction}

In a previous communication (1) we have already described the reaction of an invertebrate lectin with various human serum glycoproteins, especially after they have been treated with neuraminidase. It was concluded that most, if not all, of the precipitin reactions were due to (the uncovering of) terminal, non-

1) Supported by the Deutsche Forschungsgemeinschaft.
2) Paper XXXIII of the series Studies on Lectins.

J. Clin. Chem. Clin. Biochem. / Vol. 16, 1978. / No. 1 reducing $\beta$ - $D$-galactosyl residues. On the other hand, quite a number of different cross reactions, identity and non-complete-identity reactions could be observed. This led to the assumption, that many structural and steric differences do occur among these glycoproteins, also with respect to the serological availability of the carbohydrate groups. On the basis of these results, we investigated the possibility of further subdividing or classifying serum glycoproteins with the aid of lectin markers for their carbohydrate chains. 


\section{Material and Methods}

\section{Material}

\section{Preparation of 0 -glycosylpolyacrylamide copolymers}

Water soluble O-glycosylpolyacrylamide copolymers were prepared by copolymerization of allylglycosides with acrylamide, dialysis and lyophilization (2). These model substances had sedimentation coefficients in the range $\mathrm{s}^{\circ} 20, \mathrm{w}=3-4 \mathrm{~S}$ and contained $10-25 \%$ sugar. Their physicochemical properties will be published elsewhere (V. Horéjsí, J. Kocourek, in preparation).

\section{Human serum glycoproteins}

These were supplied in a highly purified state by the Laboratories of the Behringwerke Marburg. We are greatly indebted to the late Dr. K. Heide and to Mr. Heinz Haupt for their great efforts in purifying these materials. Carbohydratefree proteins were given under code numbers and showed no precipitin reaction with any lectin (for instance albumin or anaphylatoxin, the latter reacted with Tridacnin only because of its basic . nature!). Only Fetuin was of bovine origin.

\section{Neuraminidase-treatment of serum glycoproteins}

Neuraminidase-treatment of purified samples of serum glycoproteins was performed as follows: $0.2 \mathrm{ml}$ of a $4 \%$ solution of the serum glycoproteins was diluted $1: 1$ with neuraminidase (Behringwerke), so that we were incubating with $100 \mathrm{U}$ of the enzyme for $4 \mathrm{~h}$ at $37^{\circ} \mathrm{C}$. This solution was then used for the test, because control experiments with neuraminidase and the lectins were negative.

\section{Techniques}

\section{Agar gel diffusion tests}

These were performed in the usual vray using Ouchterlony's technique $(1,3)$.

\section{Haemagglutination and its inhibition with simple sugars}

The haemagglutination activity was assayed by a serial dilution test tube method (4), starting with $1 \%$ lectin solution in the first tube. The inhibition activity of simple sugars was expressed as the lowest concentration of the sugar which completely inhibites the agglutination caused by diluted lectin solution (4 times more concentrated than the lowest active concentration (4)). Trypsinized erythrocytes were prepared by incubation of washed cells with $1 \%$ trypsin (Léciva, Praha) in saline at $37^{\circ} \mathrm{C}$ for $45 \mathrm{~min}$.

\section{Lectins}

\section{Tridacna haemolymph}

This was prepared according to the first communication in this series (1). The precipitin is referred to as Tridacnin. Tridacna maxima and Tridacna gigas haemolymph was used, as described previously (5). The $\beta$-D-galacto syl specificity of the Tridacna maxima Tridacnin has already been described (6). The specificity of the Tridacna gigas Tridacnin is very similar, in that it is also inhibited by $\mathrm{N}$-acetyl- $D$-galacto samine and $D$-galactose (unpublished results).

\section{Lectin from Rutilus rutilus}

Preparation of the lectin from Rutilus rutilus (roach): $150 \mathrm{~g}$ of the lyophilized Rutilus rutilus roe were pulverized and stirred $3 \mathrm{~h}$ with $750 \mathrm{ml}$ of $0.1 \mathrm{~mol} / 1$ acetate buffer (pH 5.5) containing $0.5 \mathrm{~mol} / 1 \mathrm{NaCl}$. The mixture was then centrifuged and the opalescent yellow extract was added to $300 \mathrm{ml}$ of homogenized $0-\alpha-D$-galactopyranosyl polyacrylamide gel $(7,8)$ and stirred $1 \mathrm{~h}$. The gel was washed 3 times with 11 of the buffer used for extraction, then poured onto the column $(5 \times 20 \mathrm{~cm})$ and washed with the same buffer until the effluent did not con- tain any UV absorbing material. The adsorbed lectin was eluted by $0.2 \mathrm{~mol} / 1 \dot{D}$-galactose solution in the buffer used during the whole isolation; fractions containing protein were dialysed against deionized water and lyophilized. Yield, $340 \mathrm{mg}$.

Specificity of the Rutilus lectin: The lectin was active against human $\mathrm{O}, \mathrm{A}_{1}$, and $\mathrm{A}_{2}$ erythrocytes in a concentration of $60 \mathrm{mg} / \mathrm{l}$, and against $B$ group at a concentration of $30 \mathrm{mg} / \mathrm{l}$. Trypsinization led to 4-8x enhancement of agglutinability of the cells.

The agglutination of trypsinized B group erythrocytes was inhibited by $L$-rhamnose $(10 \mathrm{mg} / \mathrm{l}), D$-galactose $(625 \mathrm{mg} / \mathrm{l})$, $L$-arabinose $(625 \mathrm{mg} / \mathrm{l})$ and lactose $(2.5 \mathrm{~g} / \mathrm{l})$, but not $D$ glucose, $D$-mannose, $\mathrm{N}$-acetyl- $D$-galactosamine, $\mathrm{N}$-acetyl$D$-glucosamine and $L$-fucose $(10 \mathrm{~g} / \mathrm{l})$. On addition of solid $L$-rhamnose or $D$-galactose to the lectin solution a slight turbidity developed, which was not observed with other sugars.

The lectin was soluble and stabile in $0.1 \mathrm{~mol} / 1$ acetate buffer $\mathrm{pH} \mathrm{5.5)} \mathrm{containing} 0.5 \mathrm{~mol} / 1 \mathrm{NaCl}$. At lower ionic strength or higher $\mathrm{pH}$ the lectin rapidly aggregated and precipitated. The lectin precipitated strongly with acrylamide copolymers containing allyl- $\alpha-L$-rhamnoside or $\alpha-D$-galactoside, less with copolymers containing $\beta$-lactoside or $L$-arabino side residues, and not all with copolymers containing $D$-glucose, $D$-arabinose, or $D$-xylose residues. It reacts with quite a number of glycosubstances and even lectins, including Tridacnin.

The physicochemical properties of this and other fish roe lectins will be published elsewhere (A. Krajhanzl, V. Hořejsí, J. Kocourek, in preparation).

\section{Lectins from Ricinus communis}

Ricinus communis lectins were isolated by affinity chromatography of the haemagglutination active fraction from an extract of castor bean seeds (precipitated at $30-60 \%$ saturation by $\left.\left(\mathrm{NH}_{4}\right)_{2} \mathrm{SO}_{4}\right)$, on 0 - $\beta$-lactosylpolyacrylamide gel. The specifically adsorbed lectins were eluted by $0.2 \mathrm{~mol} / 1 \mathrm{D}$-galactose solution, dialysed and lyophilized (8). The agglutinin $\left(\mathrm{M}_{\mathrm{r}}\right)$ $120,000)$ which was used as precipitin in this study was separated from toxin $\left(M_{r} 60,000\right)$ by gel filtration on Sephadex $G-100$.

\section{Lectin from Ononis spinosa}

Ononis spinosa lectin was prepared from the root of the plant. The dried and pulverized root was extracted with water and the extract was fractionated by $\left(\mathrm{NH}_{4}\right)_{2} \mathrm{SO}_{4}$ precipitation. The active fraction ( $0-50 \%$ saturation) was dialysed, lyophilized and then applied on the column of $O-\beta$-lacto sylpolyacrylamide gel. The adsorbed lectin was eluted by $0.2 \mathrm{~mol} / 1 \mathrm{D}$-galactose or lactose, dialysed and lyophilized. The isolated lectin was relatively anti-H specific and the agglutinating activity was inhibited by $\mathrm{N}$-acetyl- $D$-galactosamine, lactose or $D$-galactose.

\section{Lectin from Glycine soja}

Glycine soja lectin was isolated by affinity chromatography of the seed extract on $\mathrm{N}$-acetyl-a-D-galactosaminylpolyacrylamide gel. The lectin was eluted with $0.2 \mathrm{~mol} / 1 D$-galactose solution, dialysed and lyophilized.

Details of isolation and characterization of these and other lectins will be the subject of another publication ( $V$. Hořejsí, J. Kocourek, in preparation).

\section{Lectin from Abrus precatorius}

Abrus precatorius seeds ( $200 \mathrm{~g}$ ), red variety collected from Ind ia, were suspended in $8.5 \mathrm{~g} / 1 \mathrm{NaCl}(1 \mathrm{l})$ at $5^{\circ} \mathrm{C}$ for two days and then homogenized in a Waring Blender. The mixture was centrifuged at $8000 \mathrm{rpm}$ in a Sorvall Ro-2 centrifuge. The clear supernatant $(200 \mathrm{ml})$ was fractionated with $\left(\mathrm{NH}_{4}\right)_{2} \mathrm{SO}_{4}$ up to $80 \%$ saturation. The precipitate formed in each fraction was removed by centrifugation at $10 ; 000 \mathrm{rpm}$ for $30 \mathrm{~min}$, dissolved in a minimum volume of water, then dialysed against distilled water until free from ammonium ions (negative to 
Nessler's reagent). The precipitate formed during dialysis was removed at $18,000 \mathrm{rpm}$ for $30 \mathrm{~min}$ and the supernatants were lyophilized. The fraction obtained between 36 and $55 \%$ saturation of $\left(\mathrm{NH}_{4}\right)_{2} \mathrm{SO}_{4}$ showed most haemagglutinating activity (titer $8 \times 10^{6}$ ) with human red cells. The lectin is inhibited by galactose and galactose-containing carbohydrates, like lactose. It has already been described in detail by other authors $(9,10)$.

\section{Lectin from Axinella polypoides}

Axinella polypoides lectin was gift from Dr. Hagen Bretting, Zoolog isches Institut and Museum, University of Hamburg. It is a mixture of two agglutinins which are inhibited by glyco-substances with terminal $D$-galactosyl residues, preferably $\beta-1 \rightarrow 6$ linked $(11,12)$.

\section{Mouse myeloma protein}

The sample J 539, already described in a previous paper (13) was used.

\section{Results}

The results of our precipitin experiments are given in table 1 . The different neuraminidase-treated serum glycoproteins are listed in the first column, and their precipitin reactions with different lectins are shown in the neighbouring columns.

Whereas the results with Tridacna maxima lectin have already been discussed elsewhere (1), the experiments with the roach roe (Rutilus rutilus) lectin were quite interesting. Although it also reacts with $D$-galactose, only a few glycoproteins are precipitated, irrespective of whether they are treated with neuraminidase or not. This fact favours the assumption, that the corresponding receptor is not terminal, but innerchain linked $D$. galactose. This finding is also strongly supported by the result with $\beta_{2}$-glycoprotein III, which only reacts with Rutilus lectin, showing no reaction with any of the other lectins, all of which, as far as we know, are directed against terminal, $D$-galactosyl residues. On the other hand, most of these lectins react with Rutilusnegative glycoproteins.

The reaction of all $\beta-D$-galactosyl specific lectins with serum glycoproteins, especially those treated with neuraminidase, is in agreement with our present knowledge of the structure of the glycoprotein carbohydrate chains $(14,15)$. Differences in the strength of inter-

Tab. 1. Precipitation of lectins with serum glycoproteins.

\begin{tabular}{|c|c|c|c|c|c|c|c|c|}
\hline $\begin{array}{l}\text { Serum glycoprotein } \\
\text { after neuraminidase- } \\
\text { treatment }\end{array}$ & $\begin{array}{l}\text { Precipitatin } \\
\text { Tridacna } \\
\text { maxima }\end{array}$ & $\begin{array}{l}\text { lectins from } \\
\text { Tridacna } \\
\text { gigas }\end{array}$ & $\begin{array}{l}\text { Rutilus* } \\
\text { rutilus }\end{array}$ & $\begin{array}{l}\text { Ricinus } \\
\text { communis }\end{array}$ & $\begin{array}{l}\text { Glycine } \\
\text { soja }\end{array}$ & $\begin{array}{l}\text { Ononis } \\
\text { spinosa }\end{array}$ & $\begin{array}{l}\text { Axinella } \\
\text { polypoides }\end{array}$ & $\begin{array}{l}\text { Abrus } \\
\text { precatorius }\end{array}$ \\
\hline Antithrombin III & + & - & - & + & - & - & - & + \\
\hline Haemopexin & ++ & + & - & + & ++ & ++ & - & + \\
\hline Transferrin & - & - & - & + & - & - & - & - \\
\hline$\alpha_{1} S$-Gly coprotein & + & - & - & + & + & + & - & + \\
\hline Fetuin & + & - & - & + & + & ++ & - & + \\
\hline$\beta_{2}$-Glycoprotein I & ++ & + & - & ++ & $+t$ & + & ++ & ++ \\
\hline Cholinesterase & ++ & + & + & ++ & + & + & + & ++ \\
\hline$\alpha_{1}$ B-Glycoprotein & - & - & + & + & - & - & - & + \\
\hline $3,1 \mathrm{~S}-\alpha_{2}$-Glycoprotein & + & $=$ & - & ++ & + & + & - & ++ \\
\hline$\alpha_{1}$-Antitrypsin & - & + & - & + & - & - & - & + \\
\hline$\alpha_{2}$ HS-Gly coprotein & - & - & - & + & - & - & - & + \\
\hline$\alpha_{2}$-Macroglobulin & ++ & + & + & ++ & + & + & ++ & ++ \\
\hline$\alpha_{1}$-Antichymotrypsin & ++ & + & + & ++ & ++ & ++ & - & ++ \\
\hline $8 S-\alpha_{3}-$ Glycoprotein & ++ & + & + & + & + & ++ & - & ++ \\
\hline$\beta_{2}$-Glycoprotein III & $\check{-}$ & - & + & - & - & - & - & - \\
\hline Gc-Globulin & - & - & - & + & - & $=$ & - & - \\
\hline Secretory component & + & + & + & + & + & ++ & - & ++ \\
\hline Lactoferrin & $+t$ & + & - & + & + & + & - & ++ \\
\hline Prothrombin & 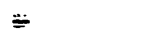 & - & ++ & + & - & + & - & - \\
\hline Inter- $\alpha$-trypsininhibitor & + & - & ++ & + & + & + & - & + \\
\hline C3-Activator & + & + & - & + & + & - & + & ++ \\
\hline $3,8 \mathrm{~S}-\alpha_{2}-$ Glycoprotein & - & - & $=$ & ++ & - & - & - & + \\
\hline Coeruloplasmin & - & + & + & ++ & + & + & - & + \\
\hline C1-Inạctivator & + & + & ++ & + & + & ++ & - & ++ \\
\hline $9,5 \mathrm{~S}-\alpha_{1}-$ Glycoprotein & - & - & $+t$ & ++ & - & - & + & ++ \\
\hline Haptoglobin & + & + & + & ++ & ++ & + & - & ++ \\
\hline $\begin{array}{l}\text { Thyroxin binding } \\
\text { globulin }\end{array}$ & ++ & + & + & ++ & + & + & - & ++ \\
\hline IgA & + & - & - & ++ & - & ++ & - & ++ \\
\hline IgM & + & + & + & + & - & ++ & - & + \\
\hline IgD & - & $=$ & + & ++ & - & - & - & + \\
\hline IgG & + & - & - & - & - & - & - & - \\
\hline IgE & ++ & + & + & $+t$ & $+t$ & + & ++ & ++ \\
\hline
\end{tabular}


action of various $D$-galactosyl specific lectins clearly reflects different requirements of these lectins for steric arrangements of the interacting carbohydrate groups.

In this respect, some of these glycoproteins give very strong precipitation reactions, and carry polyvalent lectin receptors within or on their carbohydrate groups: Cholinesterase, $\alpha_{1}$-antichymotrypsin, 8S- $\alpha_{3}$-glycoprotein, secretory component $(\operatorname{Ig} A)$, inter- $\alpha$-trypsin-inhibitor, haptoglobin and $\mathrm{IgE}$.

The precipitin reactions of IgE are very interesting; this was obtained from a myeloma patient and was more than $98 \%$ pure. A characteristic precipitin pattern with a typical set of anti-galactose lectins is presented in figure 1.

In addition, we have observed a weak reaction of $\operatorname{IgE}$ with Pneumococcus type XIV antiserum (unpublished results).

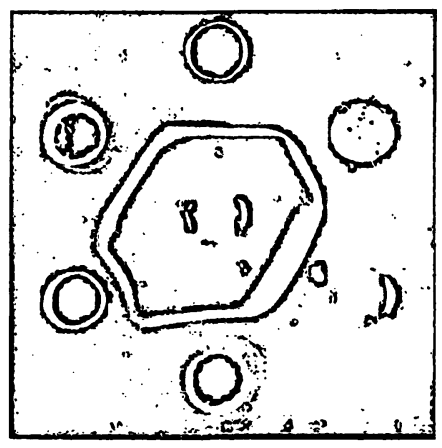

Fig. 1. Typical precipitin pattern between a glycoprotein (neuraminidase-treated IgE, in the middle) and different anti-galactosido-specific lectins (from 12 o'clock on clockwise):
$1=$ Tridacna maxima Tridacnin
$2=$ Tridacna gigas Tridacnin
$3=$ Glycine soja lectin
$4=$ Ricinus communis lectin
$5=$ Axinella polypoides lectin
$6=$ Ononis spinosa lectin

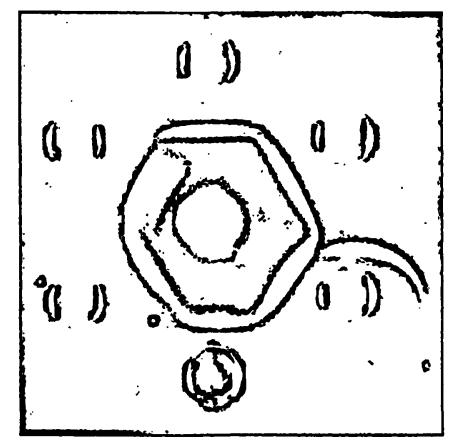

Fig. 2. Precipitin reactions of the Rutilus rutilus lectin (middle) with certain (serum) glycoproteins (from 12 o'clock on clock wise):

$1=$ Prothrombin

$2=$ Coeruloplasmin

$3=9,5 \mathrm{~S}-\alpha_{1}$-glycoprotein

$4=\beta_{2}$-glycoprotein III

$5=$ Uromucoid

$6=C_{1}$-inactivator
As an example of a precipitating lectin we have chosen the Rutilus rutilus lectin. In figure 2 we can see the precipitin reactions with different glycosubstances, which give more or less identical reactions. But this is not so with the other lectins listed in Table 1: they do not all give identical reactions with other cross reacting glycoproteins, and in many cases only partial identity is observed. This fact may subdivide these glycoproteins further and demonstrate some new relationships among them, as has been already shown in comparative studies with Tridacnin, certain serum glycoproteins and cross reacting polysaccharides or other glycosubstances (1). Also, in Figure 2, a precipitin reaction is shown between coeruloplasmin and 9,5 S- $\alpha_{1}$-glycoprotein.

In this connection it is worth mentioning, that with the exception of Rutilus rutilus lectin, these lectin give no or only very faint precipitates with serum proteins that have not been treated with neuraminidase. This may be due to the fact that Rutilus rutilus lectin can also detect certain innerchain $D$-galactose units.

The precipitin reactions of the Axinella precipitin fraction are remarkable: obviously some of the reactive glycoproteins seem to have terminal $\beta-(1-6)-D$-galactosyl structures. However, when the same glycoproteins were tested with the mouse myeloma protein, which has a very similar combining specificity (13), no precipitin reaction was observed.

The strong reaction of the Abrus precatorius lectin with most serum glycoproteins was to be expected, because of its known anti-Pneumococcal Type XIV polysaccharide cross-reactivity, i. e. it has a great affinity for terminal $\beta$-1-4-linked $D$-galactose (for instance to $\mathrm{N}$-acetyl- $D$ glucosamine) (10), a substructure which has been suggested for the neuraminic acid free cryptic core of many serum glycoproteins $(15,16)$.

\section{Discussion}

The reaction of serum glycoproteins with certain lectins offers a new possibility of characterizing serum glycoproteins with respect to their slightly differing carbohydrate moieties. This may be of importance not only for elucidating the chemical structure of the oligosaccharide chains (16) but also for studying the metabolism and fate of glycoproteins, for instance their elimination by the liver $(17,18)$.

The reactivity of lectins with glycoproteins offers a suitable means for purification of these glycoproteins using affinity chromatography on immobilized lectins. So far, mostly Con-A Sepharose has been used for these purposes (19), but lectins with specificities different. from Concanavalin A may be useful complementary tools. Most lectins used in the present study seem not to react with native, terminal sialic acid-containing glyco- 
proteins, which presents a certain limitation. The obstacle was overcome by pretreatment of the sample with neuraminidase. The most promising lectin seems to be that of the roach (Rutilus ritulis), which also reacts with untreated glycoproteins.

Finally, our observations are of clinical interest, as neuraminidase action does occur in vivo in certain cases of polyagglutinability (20). Here, in addition to the lowered or altered electrophoretic mobility, the de novo reaction with specific lectins can be of diagnostic value.

Very few, but promising stuđies have been performed so far with serum glycoproteins and lectins; in this connection the precipitation activities of Phaseolus vulgaris lectins with different sera should be mentioned (21). Extensive studies with Phaseolus vulgaris lectin and different immunglobulin classes and serum proteins have also been reported and reviewed elsewhere recently (22-26).

The fact, that the various comparative cross-reactions of serum glycoproteins, before and after removal of neuraminic acid, may lead to a new relationship between them, and may even reveal new heterogeneities among them.

\section{References}

1. Uhlenbruck, G., Steinhausen, G. \& Schwick, H. G. (1977), J. Clin. Chem. Clin. Biochem. 15, 21-26.

2. Hořejší, V. \& Kocourek, J. (1975), Abstr. No. 987, 10th FEBS Meeting Paris.

3. Uhlenbruck, G., Steinhausen, G. \& Kareem, H. A. (1976), Z. Immun.Forsch. 152, 220-230.

4. Tobiška, J. (1964), Die Phythämagglutinine, Vol. 3, Akaḍemie-Verlag Berlin.

5. Uhlenbruck, G., Steinhausen, G. \& Baldo, B. A., Comp. Biochem. Physiol. (in press).

6. Uhlenbruck, G., Baldo, B. A. \& Steinhausen, G. (1975), Z. Immun.-Forsch. 150, 354-363.

7. Hořejší, V. \& Kocourek, J. (1973), Biochịm. Biophys. Acta $297,346-351$.

8. Hořejǔí, V. \& Kocourek, J. (1974), Methods Enżymol. 34, $361-367$.

9. Olsnes, S., Saltvedt, E. \& Pihl, A. (1974), J. Biol Chem. $249,803-810$.

10. Bird, G. W. G. (1961), Experientià 17, 71-73.

11. Bretting, H. \& Kabat, E. A. (1976), Biochemistry 15 , $3228-3236$.

12. Baldo, B. A., Uhlenbruck, G. \& Steinhausen, G., Zentralbl. Biol. (in press).

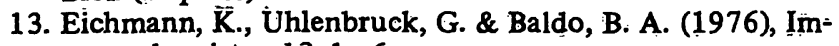
munochemistry $13,1-6$.
At the present time, lectins may render a valuable service in comparative studies (e. g. in detection of slight structural differences between different glycoproteins, polysaccharides etc.), but one must always keep in mind that it is not possible to deduce the absolute structure of carbohydrate groupings on the basis of their reactions with a lectin. The results of inhibition experiments with different carbohydrates need not reflect the true situation during the interaction of lectins with more complex glycoproteins, cell receptors etc. Similarly, no straight-forward deduction can be made about the reactivity of terminal $D$-galactose residues with our lectins, simply based on the fact that removal of terminal sialic acid and uncovering penultimate $\beta$ - $D$-galactoside residues is necessary for the "activation" of the glycoprotein. Other explanations are possible, and such a statement would be wrong and over simplified.

In a broader sense, lectins can be regarded as anticarbohydrate reagents of non antibody-like nature. They occur in plants, invertebrates and vertebrates, but we do not know very much about their function and importance in various living organisms. Their behaviour as carbohydrate recognition molecules can be exploited as a tool, and as a basis for the study of their biological function.
14. Heide, K. \& Schwick, H. G. (1973), Angew. Chem. 12, $721-733$.

15. Montreuil, J. (1975), Pure \& Appl. Chem. 42, 431-477.

16. Kornfeld, R. \& Kornfeld, S. (1976), Ann. Rev. Biochem. 45, 217-237.

17. Ashwell, G. \& Morell, A. G. (1971), in: Glycoproteins of Blood Cells and Plasma, (Jamieson, G. A. \& Greenwalt, T. J. ed.) p. 173-189, J. B. Lippincott, Philadelphia.

18. Kern, M. (1971), in l. c. (17), p. 190-203.

19. Leon, M. A. (1967), Science 158, 1325-1326.

20. Müller, H. E. (1974), Dtsch. Med. Wochenschr. 99, 1933-1940.

21. Felstedt, R. L., Leavitt, K. D. \& Bachur, N. R. (1976), Comp. Biochem. Physiol. 55 B, 417-421.

22. Lis, H. \& Sharon, N., The Antigens (Sela, M. ed.) Vol. 4. Acad. Press, New York (in press).

23. Spengler, G. A., Weber, R. \& Skvaril, F. (1972), Schweiz. Med. Wochenschir. 102, 1618-1619.

24. Jaquet, H., Wojnarowski, W., Pardoe, G. I. \& Spengler, G. A. (1975), Z. Immun.-Forsch. 150, 212-213.

25. Jaquet, H., Wojnarowski, W., Spengler, G. A. \& Pardoe, G. I. (1975), Experientia 31,721-723.

26. Terpstra, F. A. \& Smith, D. B. (1976), Canad. J. Biochem. $54,999-1001$.
Prof. Dr. G. Uhlenbruck

Abtl. für Experimentelle Innere Medizin Kerpenerstr. 15 D-5000 Köln 41 
,

. 